\title{
Production, Processing and Handling of Cow Milk in Dawa Chefa District, Amhara Region, Ethiopia
}

\section{Kefyalew Gebeyew ${ }^{1 *}$, Solomon Amakelew ${ }^{1}$, Mitku Eshetu ${ }^{2}$ and Getachew Animut ${ }^{2}$}

${ }^{1}$ College of Dry Land Agriculture, Jigjiga University, Jigjiga, PO Box 1020, Ethiopia

${ }^{2}$ School of Animal and Range Science, Haramaya University, PO Box 138, Dire Dawa, Ethiopia

"Corresponding author: Kefyalew Gebeyew, College of Dry Land Agriculture, Jigjiga University, PO Box 1020, Jigjiga, Ethiopia, Tel: +251-931-906-414; E-mail: kefyalewgebeyew@yahoo.com

Rec date: Oct 05, 2015; Acc date: Jan 02, 2016; Pub date: Jan 04, 2016

Copyright: @ 2016 Gebeyew K, et al. This is an open-access article distributed under the terms of the Creative Commons Attribution License, which permits unrestricted use, distribution, and reproduction in any medium, provided the original author and source are credited.

\begin{abstract}
The study was conducted in Dawa Chefa District, Oromia Zone of the Amhara National regional state. The aim of this study was to characterize production, processing, and handling of cow's milk. Five Kebeles namely, Gerbi Mesena, Shekila, Teref Gur, Woledi Town and Bedeno Serte were selected purposively based on their potential for milk production and variation in agro-ecology. A total of 90 households were selected from five kebeles and administrations of semi-structured questionnaire on milk, processing, and marketing practice were employed. The local cattle are the major breed used in the study area. The average number of cattle per household is 6 and ranges from 3-27. There are three major milk production systems namely, mixed crop-livestock (98\%), peri-urban (1.5) and urban (0.5) milk production system. Mixed crop-livestock production systems were the dominant production system in the study area. The percentages of milking cows are higher in the mixed croplivestock production system than in the urban milk production system. The overall estimated mean value for age at first service, age at first calving, calving interval, number of service per conception for local and crossbred cows were (29 and 27.03 month), (46.16 and 37 months), (25.86 and 21 month) and (1.61 and 1.17), respectively. Milking, processing and marketing are predominantly done by female member of the household. The main feed resources in the District were communal grazing, crop residues and crop aftermath. Natural pasture account for $54 \%$ of the feed that was available and green maize stover contributes $10 \%$ of the overall feed resources.
\end{abstract}

Keywords: Production; Milk; Marketing; Processing

\section{Abbreviation}

AFC: Age at First Calving; AFS: Age at First Service; AI: Artificial Insemination; AMMUL: Anand Milk Union Ltd; FGD: Focus Group Discussion; CSA: Central Statistical Agency; EB: Ethiopian Birr; ILCA: International Livestock Center for Africa; NGO: Nongovernmental Organization; CI: Calving Interval; NSC: Number of Services per Conception

\section{Introduction}

Ethiopia's increasing human population, urbanization trends and rising household incomes are leading to a substantial increase in the demand for livestock products, particularly milk and meat. In order to meet the growing demand for milk in Ethiopia, milk production has to grow at least at a rate of 4 percent per annum [1]. Besides, Ethiopia spends over 45 million Birr annually for importation of milk and milk products [2]. It is even getting worse due to the high population growth, which increases at a rate of 3 percent per annum [3], while the urban population increases at a rate of $4.4 \%$ [4]. Even though smallholder urban dairy production in Dawa Chefa District contributes substantially to fill in the demand-supply gap for milk; there is little information available on production, processing, and handling patterns of milk. The information generated will be valuable for researcher, policy maker, trader consumer and investors in the area of this study and allow improved interventions that stimulate sustainable milk production. Therefore, the current study aimed to characterize dairy production, processing and Handling in Dawa Chefa district.

\section{Materials and Methods}

\section{Description of study area}

The study was conducted in Dawa Cheefa district, Oromia Zone of the Amhara Regional State. The area is located at $10^{\circ} 43^{\prime} \mathrm{N}$, latitude and $39^{\circ} 52^{\prime} \mathrm{E}$ longitude. The altitude of the area ranges from 1500 to 2300 meter above sea level. The study area falls within the dry Kolla agroclimatic zone, which can be classified as semi-arid climate according to climatic classification developed in the Agro-ecological Zones of Ethiopia. The study area has a warm thermal zone and dry moisture zone (60 to 90 , growing days), which suggests a considerable level of risk to rain-fed agriculture. The rainfall distribution of the study area has highly seasonal and temporal variations.

\section{Survey}

Information relevant to production, processing and marketing of cow milk in Dewa Chefa district was generated through discussions held with key informants, Agricultural Extension Officers, Experts and Development Agents. A questionnaire-based survey was also used to collect data needed for assessment of production system, processing and handling of cow milk in the area. 
Citation: Gebeyew K, Amakelew S, Eshetu M, Animut G (2016) Production, Processing and Handling of Cow Milk in Dawa Chefa District, Amhara Region, Ethiopia. J Veterinar Sci Technol 7: 286. doi:10.4172/2157-7579.1000286

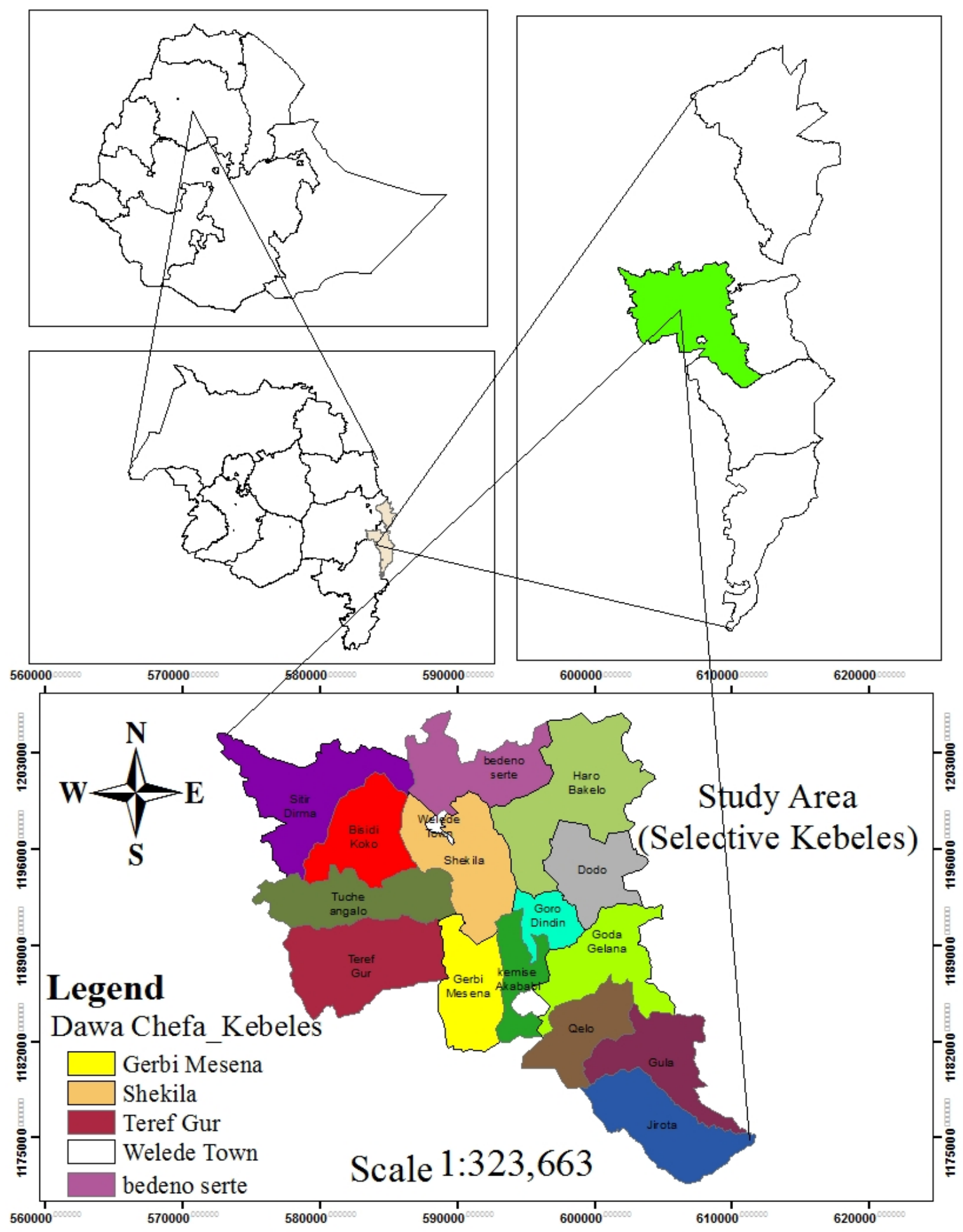

Figure 1: Map of the study area.

\section{Dairy production and processing, and marketing systems}

In order to characterize the dairy production system in the study area, farmers/producers were interviewed using a structured questionnaire which was pre-tested. Enumerators were recruited and trained before actual data collection commenced. The lactation length and daily milk offtake of zebu cattle breed and their crosses were obtained from producers; hence the total amount of milk produce in a 
Page 3 of 9

year was calculated. For the field survey, the method of data collection was single-visit-multiple-subject survey [5]. Both primary and secondary information were taken into consideration. To characterize the milk production, processing and handling of the area. Primary sources were captured via interview (structured and semi-structured interviews, and key informants interview), questionnaire, focus group discussion and practical observation. The secondary sources were also reinforced through careful examination and investigation of both published and unpublished documents.

\section{Sampling technique and size}

Both purposive and random sampling techniques were employed as a representative for the whole sample framework. The first sampling technique was purposive to select five 'Kebeles' out of 15. Five Kebeles, namely, Gerbi Mesena, Shekila, Teref Gur, Woledi Town and Bedeno Serte were selected purposively based on their potential for milk production. The second sampling technique is systematic random sampling which employed to find the respondents at household level and from extension agents (workers) in the purposively selected 'Kebeles'. The target sampling population was defined as all household in the study area who owned milk cows and $10 \%$ of the household were selected randomly from a list of farmers registered as milk producers of the respective kebeles. That is $100 \%$ (5) of the extension workers from the purposively selected Kebeles are considered for group discussion. The total number of respondents was 115. Out of the total number of respondents for the study, 15 were used for focus group discussion (FGD), 90 to fill out questionnaires and 10 for interview.

\section{Data management and statistical analysis}

The survey data was analyzed using (SPSS) Version 16 to analyze the milk production, Processing and handling data.

\section{Results and Discussion}

\section{Socio-economic characteristics of the respondents}

Out of the total interviewed dairy cattle producers $(\mathrm{N}=90), 82.76 \%$ were males and the rest were female household members of different age and educational status. From the interviewed households, 71.11\% were illiterate and only $10 \%$ of them are at elementary educational level (Table 1). The role of education is obvious in affecting household income, adopting technologies, demography, health, and as a whole the socio-economic status of the family [6]. In this finding, family member at elementary school level of education exceeds the proportion of those at higher educational level (Table 1). The percentage of illiterate family members $(71.11 \%)$ reported in this study was greater than the reported figure by Berhanu G [7] which was 50\% for Bure district.

\section{Involvement of family member in dairy production}

As the survey result showed, dairy production activity in the study area is done by both female and male family members, and about $39 \%$ of the boys in the range of 7-14 years of age are involved in cattle herding. Milking, processing and marketing of milk and dairy products are performed mainly by the female or housewife. Almost all cows are hand milked, and milking of cows was practiced by housewife. In addition to these the housewife performs cleaning of barn.

\begin{tabular}{|l|l|l|}
\hline Educational status & $\begin{array}{l}\text { Number of respondent } \\
(\mathbf{N}=\mathbf{9 0})\end{array}$ & Percent of respondents \\
\hline Illiterate & 64 & 71.11 \\
\hline Read and write & 12 & 13.33 \\
\hline Elementary school & 9 & 10 \\
\hline High school & 5 & 5.55 \\
\hline Diploma and above & - & - \\
\hline Total & 90 & 100 \\
\hline
\end{tabular}

Table 1: Educational status of sample respondents in Dawa Chefa District. $\mathrm{N}=$ number of respondents.

\section{Dairy production system in the study area}

Mixed crop-livestock production system is the predominant system in the study area and similar to most other northern part of the region. The major crop grown includes maize, sorghum, khat, teff, and haricot bean. Sorghum and maize was the predominant crops grown throughout the study area. Other crops are grown at different intensity in different Kebeles. Cattle, goat, sheep, camel and poultry are the major livestock species found in the study area that are integral part of farming system. From livestock species, cattle are mainly reared for milk and draft power while sheep and goat are reared for income generation. In the study area two dairy production systems were identified, i.e., mixed crop-livestock, peri-urban and urban milk production system.

\section{Mixed crop-livestock production}

Data from Dewa Chefa district Agricultural Office showed that the estimated number of the milking cows in this system to be about 10,528. According to the current study, in these system cows are not specialized for milk production. However, they are reared to produce drought oxen. This production system was constrained by feed, capital, disease mainly trypanosomiasis and internal parasites and genotype problems that are still hindering the milk outputs. The local breeds used for milk production were undefined zebu and their crosses from Holstein Frisian. The main feed sources in this production system were the uncontrolled communal grazing lands, crop residues and crop aftermath, which is in agreement with the finding of Mohamed AMA [8]. There is little or no practice of developing improved forages in the study area. There is no much care for the calves born and the calves are allowed to suckle the dam for 30-40 days after that they graze on green forages in the homestead. According to the current study the mixed crop-livestock milk production system contribute about $98 \%$ of the total milk production in the district.

\section{Urban and peri-urban milk production system}

The survey result shows that, this system was mainly predominant in areas of small town of Dawa Chefa district namely Welede Town, and Shekila. The urban and peri urban milk production system contributes only $2 \%$ of the total milk production in the district. In this system milk producers had little or no market orientation. Milk producers under this system are inclined to use improved forage variety and better health supervision of their livestock. The feed resources in Welede Town and Shekila were natural communal and 
private grazing, hay, oil seed cake and the crop residues of teff, maize, and finger millet, purchased concentrates (wheat bran and noug seed cake), and roughage of conventional and non-conventional type (maize stover, sugar cane topes, and hay). The urban milk production system in this area was found to be similar to what [9] characterized in Shashemene and Dilla areas of Southern Ethiopia in its market orientation and by the type of inputs used, particularly feeds. Indigenous cattle breeds are the dominant cattle breeds kept in this system. In Welede Town and Shekila, there were 89 dairy producers out of which 37 of them have crossbreds.

\section{Reproductive and productive performance of cows}

Age at first service: The average ages at first service (AFS) of local and crossbred heifers were 29 and 27.03 months, respectively (Table 2). The result of AFS reported for local Zebu heifers in this study is in the range of that noted for the central highlands and in Addis Ababa milk shed areas [10], whereas greater values of 44 months for local and 35.7 months for crossbred heifers have been reported [11]. Different environmental factors advance or delay AFS, especially nutrition determine prepubertal growth rates, reproductive organ development, and onset of puberty and subsequent fertility. Substantial evidence exists that dietary supplementation of heifers during their growth will reduce the interval from birth to first services and calving [12], probably because heifers that grow faster cycle earlier and express estrus.

\begin{tabular}{|l|l|l|}
\hline Parameters & Local breed & Crossbred \\
\hline AFS (months) & $29 \pm 6.9$ & $27.03 \pm 2.11$ \\
\hline AFC (months) & $46.16 \pm 0.5$ & $37 \pm 2.1$ \\
\hline NSC & $1.61 \pm 0.05$ & $1.75 \pm 0.17$ \\
\hline Cl (months) & $25.86 \pm 9.2$ & $21.2 \pm 8.7$ \\
\hline
\end{tabular}

Table 2: Reproductive performance (mean $( \pm \mathrm{SD})$ ) of dairy cattle in the study area. $\mathrm{AFS}=$ age at first service; $\mathrm{AFC}=$ age at first calving; $\mathrm{CI}=$ calving interval; $\mathrm{NSC}=$ number of services per conception.

Age at first calving: The reported average age at first calving (AFC) of local and crossbred heifers in this study were 46.16 and 37 months, respectively. The result of this study for local zebus is almost similar with what was reported by 13 . McDowell RE [13] for Horro breed (50 months) but is less than the AFC reported by Mukasa-Mugerwa [14] for local cows (53 month) and [11] for Fogera cows (54.6 months). The result depicted for crossbred cows in this study was higher than what was reported by Alberro M [15] for Fresian x Zebu cows (29.1 months). This variation might be due to the difference in the level of management and other inputs as this figure is an on-farm finding in contrast the work of Alberro M [15].

Number of service per conception: The reported average number of services per conception (NSC) of local and crossbred cows was 1.61 and 1.75 , respectively. Similar estimates were reported by other investigators in Ethiopia for crossbred cows, all in the range of 1.5 to $2.5[16,10]$. According to Mukasa-Mugerwa [14], cows with values of NSC greater than two are regarded as poor. However, the higher figure NSC in crossbred cows (1.75) might be attributed to the low efficiency of artificial insemination (AI) services for various reported reasons like lack of skilled AI technician, non-synchronization of heat and insemination and lack of effective frozen semen in the district.
Calving interval: The result of this study depicted that the calving intervals (CI) of local and cross bred cows were 25.86 and 21.2 months, respectively. The reported $\mathrm{CI}$ in this study was almost similar to the estimates of Mukasa-Mugerwa E [14] (25 months) in zebu cattle. However, it was much higher than that noted by McDowell [13] for Horro breed (12.2 months); for Arsi breed (12.9 months); and for Fogera breed (18.6 months) [11].

\section{Lactation length and average milk yield of cows}

The lactation length of animals in the study area depended mostly on the management objective of the herder; the herder may prolong the lactation length for the sake of continuous milk supply or dry off the cow at early stage for breeding purpose [17]. The average lactation length for dairy cows in the study area was 8.37 months (Table 3 ). The result of the current study lower than the report of Lemma $F$ [18] who indicates that, an average lactation length in the East Shewa Zone of Oromia region was 9.5 month.

\begin{tabular}{|l|l|l|}
\hline Kebeles & Number of Cows & Lactation length (months) \\
\hline Gerbi & 20 & 8.44 \\
\hline Shekila & 25 & 8.61 \\
\hline Welede & 19 & 8.56 \\
\hline Bedeno & 24 & 8.12 \\
\hline Teref & 12 & 8.11 \\
\hline Overall & 100 & 8.37 \\
\hline
\end{tabular}

Table 3: Average Lactation length of local cow's in different Kebeles in Dawa Chefa District.

The mean daily milk yields of cows per head during the early, mid and late stages of lactation were 2.13 liters, 1.45 liters and 0.90 liters, respectively (Table 4 ). The overall cow's milk yield /head per day were 1.49 litters. Similarly, the reported average milk yields for the different stages of lactation in this study were higher than what was reported by Asaminew T [19] in Mecha and Bahir Dar Zuria Districts, which was 2.0, 1.2 and 0.6 litters for the early, mid and late lactations, respectively with an overall average milk yield of 1.2 litters/day for local cows.

\begin{tabular}{|l|l|l|l|l|}
\hline \multirow{2}{*}{ Kebeles } & \multicolumn{4}{l}{ Daily milk yield (liters) } \\
\cline { 2 - 5 } & Early & Mid & Late & Overall \\
\hline Gerbi & 2.03 & 1.38 & 0.88 & 1.43 \\
\hline Shekila & 2.07 & 1.47 & 0.86 & 1.46 \\
\hline Weledi & 2.05 & 1.52 & 0.97 & 1.51 \\
\hline Bedeno & 2.09 & 1.45 & 0.93 & 1.49 \\
\hline Teref & 2.04 & 1.41 & 0.86 & 1.43 \\
\hline Average & 2.13 & 1.45 & 0.90 & 1.49 \\
\hline
\end{tabular}

Table 4: Milk yield of local cows in different stages of lactation at different Kebeles of Dawa Chefa district.

In general, the higher the average daily milk yield per cow and the variation in lactation length in the present study might be attributed to 
Page 5 of 9

the difference in agro-ecology, nature of research (on-farm vs. onstation) and breed of animals used.

\section{Breed and breeding practices}

In Ethiopia indigenous animals are the dominant source of milk across all the production systems. During the breeding season some farmers breed their cows and heifers by the superior bulls owned by themselves or their neighbors (22\%). Most of the farmers breed their cows by any bull $(78 \%)$ available in the herd when their cows come to heat. $73.3 \%$ of the respondents use local bulls for mating followed by $26.6 \%$ that use AI service. This finding confirms the claim that AI is not commonly used in many tropical milk production systems, and natural service using a bull is commonly practiced [20]. Therefore, work in areas of AI deserves more attention to reduce the reported low conception rate in AI by synchronizing the peak heat period and the time of insemination. Only $6.65 \%$ of the respondents have crossbred animals. The sources of crossbred milk animals were government, NGO market, and AI. According to the respondents, 53.3\% cows come into heat mostly in the dry season particularly during September to January when adequate feed resources were available. About $4.5 \%$ of the respondents replied that their cows come into heat during the rainy season and $42.2 \%$ responded both during rainy and dry seasons (Table $5)$.

\begin{tabular}{|l|l|}
\hline Mating system & Percent of the respondents \\
\hline Natural mating & 73.4 \\
\hline Al & 26.6 \\
\hline Breeding bulls & 78 \\
\hline Any bulls & 22 \\
\hline Superior bulls & 2 \\
\hline
\end{tabular}

Table 5: Mating system and types of breeding bull in the study.

Only $32.5 \%$ of the respondents have breeding bull. Mostly breeding bulls are freely used, to serve own and neighbor herds. Only $3.6 \%$ of the respondents exercise seasonal mating for various reasons like feed shortage and to ensure year round supply of milk. This showed that controlled and planned mating is not the most common practice in the study area. Therefore, awareness should be created in the area for planned and controlled mating to synchronize delivery of calves in seasons of better feed availability. About $53.3 \%$ of the respondents answered that the peak mating season is during December to January. According to milk producers, the main reported sources of AI were government $(98.4 \%)$ followed by NGO (1.5\%). The main problems of $\mathrm{AI}$ in the area are lack of access $(41.1 \%)$, shortage of liquid nitrogen and semen (17.7\%), distance to AI station (16.6\%), non-effectiveness of AI (15.5\%) and unwillingness of AI technicians (11.1\%) (Table 6).

\begin{tabular}{|l|l|}
\hline Mating season & Percent of respondents \\
\hline Dry season & 53.3 \\
\hline
\end{tabular}

\begin{tabular}{|l|l|}
\hline Rainy season & 4.5 \\
\hline Both & 42.2 \\
\hline Sources of Al & 98.4 \\
\hline Government & 1.5 \\
\hline NGO & \\
\hline Problem of Al & 41.1 \\
\hline Lack of access to Al & 16.6 \\
\hline Distance to Al station & 15.5 \\
\hline Non- effectiveness of Al & 17.7 \\
\hline Shortage of liquid nitrogen and semen & 11.1 \\
\hline unwillingness of Al technicians &
\end{tabular}

Table 6: Mating season, sources of AI and problems of AI in the study area.

\section{Milking and milk handling practices}

In the study area all of the interviewed households practiced hand milking. $76 \%$ of the cows in the study area are milked twice a day and $24 \%$ of households milk their cows once a day. One of the major factors affecting the quality of dairy product is related to milk utensils. The type and quality of milking utensil used as well as method of milking affect the quality of milk and its product. With regard to the type and quality of milking utensil, majority ( $99 \%$ ) of the interviewed households use traditional milk utensils such as Etecha, Okole, clay pot and Chocho (Figure 2). Frequency and method of cleaning milk utensil is not good in study area. All respondents in the study area smoke milking utensil. The main purpose of smoking milk utensil is to give attractive smell and taste of milk. The plant species that are used for smoking are olea africana (Ejersa), Premna resinosa (Tetessa) and Terminalla brownie (Biressa).

Equipment used for milking, processing and storage of milk determine the quality of milk and milk products. All respondents in the study area used okole and chocho as milking utensil. The use of traditional containers can be a potential source for the contamination of milk by bacteria, because this allows the multiplication of bacteria on milk contact surfaces during the interval between milking. This is mainly due to the difficulty of removing all milk residues from traditional containers that are porous by nature with the common cleaning systems. Producers need, therefore, to pay particular attention for the type as well as cleanliness of milk equipment. Milking equipment should be easy to clean, and as such aluminum and stainless steel equipment are mostly preferred. Moreover, half of the respondents $(50 \%)$ fail to wash udder before and after milking, and those that wash udder use cold water to do so (Table 7). This also may contribute to unhygienic way of milking that may lead to microbial contamination of milk. 
Citation: Gebeyew K, Amakelew S, Eshetu M, Animut G (2016) Production, Processing and Handling of Cow Milk in Dawa Chefa District, Amhara Region, Ethiopia. J Veterinar Sci Technol 7: 286. doi:10.4172/2157-7579.1000286

Page 6 of 9

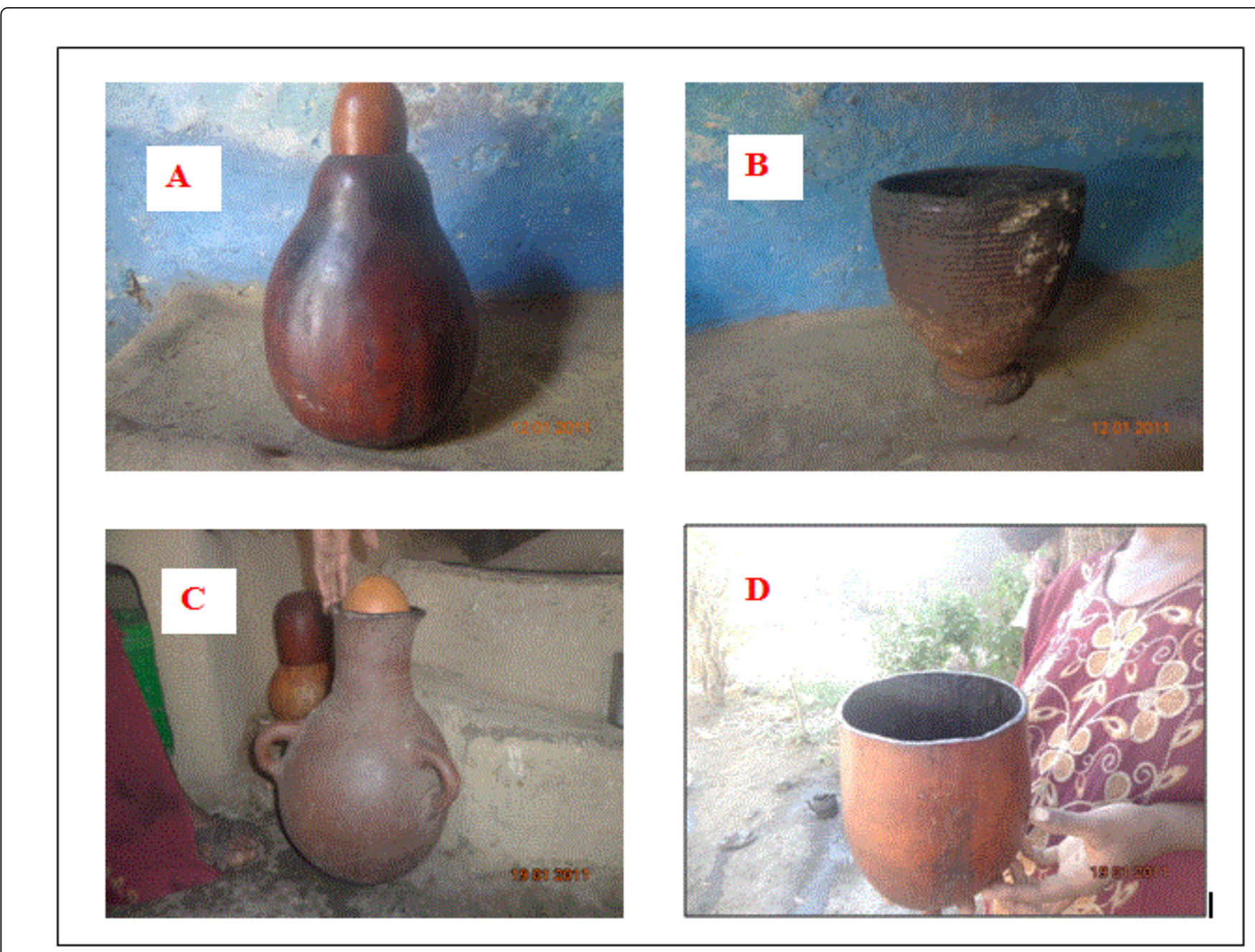

Figure 2: Traditional milk utensils $(\mathrm{A}=$ Etecha; $\mathrm{B}=$ Chocho; $\mathrm{C}=$ clay pot, $\mathrm{D}=$ Okole $)$ used in the study area.

\begin{tabular}{|l|l|}
\hline Hygienic procedures & $\begin{array}{l}\text { Number } \\
\text { respondents }\end{array}$ \\
\hline Producers followed during milking \\
\hline Washing udder before and after milking & $40(43.3 \%)$ \\
\hline Washing udder before milking only & $6(6.6 \%)$ \\
\hline No washing at all & $45(50 \%)$ \\
\hline Type of water used for udder washing \\
\hline Cold & $58(64.4 \%)$ \\
\hline Warm & $25(27.7 \%)$ \\
\hline Both alternatively & $7(7.78 \%)$ \\
\hline
\end{tabular}

Table 7: Milk hygiene practice in the study area.

\section{Housing and cleaning practice}

According to the present study $53.3 \%$ of the interviewed households use the same house with their animal and the remaining $46.6 \%$

household used separate house for their cows. The purpose of housing in the study area was to protect cattle from theft and predators. Housing of cattle and its purpose observed in this study were similar with other reports [19]. Dry and comfortable bedding condition is important to minimize the growth of pathogenic microorganisms. In the present study $5 \%$ of the respondents used grass and cereal straw as the bedding material, while the rest do not use bedding material (Table 8). Used bedding has been shown to harbor large number of microorganism [21], which might expose the teat end to these microorganisms. Wet and muddy pens also increase the risk of occurrence of mastitis and milk contamination [22]. About 35\% of the respondents clean the barn three times a week, while $41 \%$ clean two times and only $24 \%$ of them reported to clean the barn daily.

\begin{tabular}{|l|l|}
\hline Variables & Percent of the respondent (N=90) \\
\hline Barn type & 53 \\
\hline Confined house & 46 \\
\hline Separate house & \\
\hline Bedding used & \\
\hline
\end{tabular}




\begin{tabular}{|l|l|}
\hline Bedding & 5 \\
\hline No bedding & 95 \\
\hline \multicolumn{2}{|l|}{ Frequency of cleaning barn } \\
\hline Three times a week & 35 \\
\hline Two times a week & 41 \\
\hline Daily & 24 \\
\hline
\end{tabular}

Table 8: Barn type, bedding and frequency of barn cleaning in the study area.

\section{Sources and distance to water}

In the study area the main sources of water are rivers, dams, wells and boreholes. The majority (53 \%) of the households obtained water from the rivers or dam, while $28 \%$ had wells and $19 \%$ used boreholes. Most of the households expressed unreliability of river water as rivers tended to dry during the dry season. The wells were dig at homesteads, mostly within distance of 500 meters, while boreholes were communal assets usually drilled in grazing areas. The distance to water tended to affect the frequency of watering cattle, as $40 \%$ of the households lived 1-2 $\mathrm{km}$ away from the source of water, while $20 \%$ lived between $2-3$ kilometers away. The households who lived far from the source of water reported that they drive the animals to drink water once per day, or the water was carried home using water carts (Table 9).

\begin{tabular}{|l|l|}
\hline Sources of water & Percent of respondents \\
\hline River or dam & 53 \\
\hline Wells & 28 \\
\hline Bore holes & 19 \\
\hline Distance of water & \\
\hline $500 \mathrm{~m}$ & 40 \\
\hline $1-2 \mathrm{~km}$ & 40 \\
\hline $2-3 \mathrm{~km}$ & 20 \\
\hline
\end{tabular}

Table 9: Sources and distance of water in the study area.

\section{Milk processing in the study area}

The household in the study area used, only traditional milking utensils for collecting or milking, storing and processing were observed. Due to technical and economic constraints, the major dairy products found in the study area were yoghurt-like fermented/sour milk (Ergo), traditional butter (Kibe), traditional ghee (Neter Kibe), and cottage cheese (Ayib). Similar information was noted by Sintayehu Y, Shiferaw Y and Gonfa A $[9,10,23]$.

\section{Fresh milk}

The survey results showed that milk producers used different techniques to preserve fresh milk without clotting, such as smoking of the container and boiling of fresh milk, or refrigeration. In the study area, smoking was the predominant practice performed by $100 \%$ of the households. About $13 \%$ of the households use refrigerator, an option which was almost not present in the mixed crop-livestock and peri- urban areas. Cooling by putting the container with milk into a coldwater bath was practiced by about $4.8 \%$ of the peri-urban producers. It is obvious therefore, that for technical and economic reasons technologies in fluid milk processing such as steampasteurization, sterilization and aseptic packing are not common on Ethiopian smallholder farms $[9,10,22]$.

\section{Fermented/sour milk (Ergo)}

Ergo typically is semi-solid and in smallholder dairy farms it is produced from whole milk, while in milk cooperatives or other producer groups it is produced from skim milk. On average, milk is stored in a clay pot or a gourd over a period of 1 to 4 days and allowed to develop acidity. The mean shelf life of fermented milk was 3.8 days. According to the information collected from the respondents, fermented milk was the main product used as basis for further processing of various fermented milk products such as traditional butter, ghee, cottage cheese, butter milk and whey.

\section{Traditional butter (Kibe)}

Among respondents $96.63 \%$ produce butter. Traditional Ethiopian butter (kibe) is made from soured milk (ergo); cream is not used. The sour milk is placed in a clay churn or a bottle gourd. Churns are usually spherical, with a neck $10 \mathrm{~cm}$ in diameter at the narrowest point and a vent of $0.5 \mathrm{~cm}$ in diameter near the neck. The churn may have previously been smoked with Olea africana. Besides imparting a distinct flavor to the butter, this practice has a bacteria-static effect, and may reduce processing time by heating the churn. After filling, the churn stopper with a plug, a false banana leaf, or a piece of skin or leather stretched over the mouth and securely tied. The break point, i.e., the point when butter starts to form, can be detected by a change in the sound of the milk. Many dairy women also insert a straw into the churn through the vent: if there are small butter grains adhering to the surface of the straw, the break point has been reached. After churning for a few more minutes the straw is again inserted through the vent. If the straw is clean this indicates that the butter granules have coalesced into larger grains. The churn is then rotated on its base; the grains which collected in the centre form lumps of butter which are skimmed off. The butter is then kneaded in cold water and washed to remove visible residual buttermilk. Butter is stored for about 10 days without spoilage. The farmer used local preservation method to protect the butter from spoilage. The main purposes of butter in the study area were for hair ointment, home consumption and for cash income by selling the butter. About $33.49 \%$ of the household use butter for cash income $32.53 \%$ for hair ointment and the remaining $33.97 \%$ use for home consumption.

\section{Cottage cheese (Ayib)}

Local cheese is one of the milk products produced in the study area but it is not commonly made. It is produced only by $17.7 \%$ of the household of the area. Cottage cheese is a soft curd-type cheese made by churning the buttermilk mainly at household level, while in one farm and in milk cooperatives or other producer groups it was produced from skim milk. Cottage cheese was prepared by heating the buttermilk in an iron or clay pot until a curd-mass formed; followed by cooling to coagulate the curd. Then, the curd was separated from the whey through a fine meshed cloth or a sieve. ELFORA were the only cheese producing farm in Dawa Chefa district. The farm produces cheese and butter in large quantity and sold this product in Addis 
Page 8 of 9

Ababa. Generally the farmer had no much tradition in producing and using cheese.

\section{Traditional ghee (Neter Kibe)}

Another product that is produced in the study area is ghee (71.1\%). The ingredients that are used to prepare ghee in the study area are Aswanseed (trachyspermumami), Rue (Rutagraveolence) Turmeric (curcumadomestica), Thyme (thymusserrulatus), garlic (Alliumsativum), Abish (Fenugreek), cardamom (Aframomumkorerimao), ginger (Zingeberofficinale) and black cumin (Nigellasativa). Ghee is prepared from butter. The butter is heated over a low fire until all moisture had evaporated. When the non-fat solid turned to brown and frothing stops, preparation is stopped. According to the current study, the farmer store ghee from 6 month up to 7 years and used as a medicinal value. Generally, to increase the shelf life of milk products, the current practice of further processing of traditional butter and cottage cheese into traditional ghee and Metata Ayib (ripened soft cheese) was typical for most smallholder dairy farmers of Ethiopia [22] (Gonfa et al., 2001). However, most of the milk processing was done by use of traditional household utensils under unsanitary conditions; to deliver a desirable flavour, plant materials were added to the finished product (traditional ghee and Metata Ayib ( ripened soft cheese) that might have contributed to the high microbial load. This is in agreement with the report of $[9,23]$. Therefore, giving basic handling and health education for producers is likely to result in a better milk quality on the market, including shelf life and aspects of consumers' health.

\section{Feed resources}

The main feed resources in the district are communal grazing, crop residue and crop aftermath. Natural pasture accounted for $54 \%$ of the feed that was available during the wet season, while green maize stover contributed $10 \%$ of the overall feed resources. In addition to natural pasture, crop residues provide $36 \%$ of the feed during the dry season. The main crop residues include maize stover, groundnut tops and sorghum and millet stover. About $65 \%$ of the respondents produce their own feed from their own pasture, crop residue and crop aftermath and the remaining household in the district purchase feed especially pasture land from other farmer either for free grazing or cut and carry feeding system. Improved forage production is not common in the district. This is due to limited extension work, lack of information and absence of improved forage seeds in the district (Table 10).

\begin{tabular}{|l|l|}
\hline Feed resources & Percent of respondents \\
\hline Communal grazing & 54 \\
\hline Green maize Stover & 10 \\
\hline Crop residue & 36 \\
\hline
\end{tabular}

Table 10: Sources of feed for dairy cows in the study area.

\section{Conclusion}

The dairy production system in the study area were, mixed croplivestock (98\%), peri- urban (1.5\%) and urban production system $(0.5 \%)$. From this result it could be concluded that the general production system in the study area was characterized by mixed croplivestock production system.

\section{Competing Interest}

The authors declare that they have no competing interest.

\section{Authors' Contributions}

SA conceived the study, designed and conducted all laboratory experiments; analyzed and interpreted experimental results. ME, GA and KG participated in the proposal, study design and manuscript preparations. All authors read and approved the final manuscript.

\section{Acknowledgement}

I am deeply grateful and indebted to Amhara National Regional State of livestock Resources Development Promotion Agency, Kombolcha Animal Disease Survey Investigation Diagnostic Laboratory that support me by creating fertile ground to laboratory work.

\section{References}

1. Azage T (1989) Reproductive development and function in zebu and crossbred cattle in Ethiopia. Australia: James Cook University.

2. Azage T, Asfaw Y (2004) Milk production of Ada'a Liban Woreda Dairy and dairy products marketing association. ESAP Newsletter, p. 4.

3. Mohammed YK (2003) Certain aspects of the dairy systems in the Harar milk shed, Eastern Ethiopia. PhD thesis Presented to the School of Graduate Studies of University of the Free State, South Africa, p. 195.

4. Ahmed MM, Bezabih E, Jabbara MA, Tangaka F, Ehui S (2003) Economical and Nutritional impact of market oriented dairy production in Ethiopian highlands. Socioeconomic and policy research working. ILRI (international livestock research institute).

5. ILCA (International Livestock Centres for Africa) (1990) Livestock Systems Research. Kearl LC 1982 Nutrient requirement of ruminants in developing countries. International Feedstuffs Institute, Utah Agricultural Experiment Station, Utah State University, Lomgman, USA, p. 381.

6. Keralem E (2005) Honeybee production systems, opportunities and challenges in enebse Nationalities and Peoples Region), Ethiopia. MSc thesis presented to the School of Graduate Studies of Haramaya University, Ethiopia.

7. Berhanu G, Fernandez-Rivera S, Mohammed H, Mwangi W, Seid A (2007) Maize and livestock: Their inter-linked roles in meeting human needs in Ethiopia. Research Report 6 ILRI (International Livestock Research Institute), Nairobi, Kenya, p. 103.

8. Mohamed AMA, Simeon E, Yemesrach A (2004) Milk development in Ethiopia. EPTD Discussion Paper No123. Washington DC, USA. OPEDJZ (Office of Planning and Economic Development for Jimma Zone) (2002) Statistical Abstract Jimma, Oromia,

9. Sintayehu Y, Fekadu B, Azage T, Berhanu G (2008) Dairy production, processing and marketing systems of Shashemene-Dilla area, South Ethiopia. IPMS (Improving Productivity and Market Success) of Ethiopian Farmers Project Working Paper 9, ILRI (International LivestockResearchInstitute), Nairobi, Kenya p: 62.

10. Shiferaw Y, Tenhagen BA, Bekana M, Kassa T (2003) Reproductive performance of crossbred dairy cows in different production systems in the Central Highlands of Ethiopia. Trop Anim Health Prod 35: 551-561.

11. Gidey (2001) Assessment of calf crop productivity and total herd life of fogera cows at Andasa Ranch in North Western Ethiopia. School of Graduate Studies of Haramaya University.

12. Azage T (1989) Reproductive development and function in zebu and crossbred cattle in Ethiopia. Australia: James Cook University.

13. McDowell RE (1971) Feasibility of commercial milking with cattle indigenous to the tropics. Cornell International Agricultural Development Bulletin No 21, Cornell University, Ithaca, New York, USA, p. 22. 
Citation: Gebeyew K, Amakelew S, Eshetu M, Animut G (2016) Production, Processing and Handling of Cow Milk in Dawa Chefa District, Amhara Region, Ethiopia. J Veterinar Sci Technol 7: 286. doi:10.4172/2157-7579.1000286

Page 9 of 9

14. Mukasa-Mugerwa E (1989) A review of reproductive performance of female Bos indicus (Zebu) cattle. ILCA, Monograph No 6. International Livestock Center for Africa, Addis Ababa, Ethiopia.

15. Alberro M (1983) Comparative performances of F1 Friesian x Zebu heifers in Ethiopia. Journal of Animal Production 37: 247-252.

16. Beyene K (1992) Estimation of additive and non-additive genetic effects for growth, milk dry environments in Ethiopia. Dissertation, Cornell University, USA.

17. Swenson C, Schaar J, Brännäng E, Meskel LB (1981) Breeding activities of the Ethio-Swedish integrated rural development project. Part III. Reproductive performance of zebu and crossbred cattle. World Animal Review 38: 31-36.

18. Lemma F, Fekadu B, Hogde PB (2004) Rural Smallholder Milk and Dairy Products Production, Utilization and Marketing Systems in East Showa Zone of Oromia. In: Participatory Innovation and Research: Lesson for Livestock Development. Proceedings of the 12th Annual Conference of the Ethiopian Society of Animal Production (ESAP) Held in Addis Ababa, Ethiopia, August 12-14 pp: 17-28.

19. Asaminew $\mathrm{T}$ (2007) Production handling, traditional processing practices and quality of milk in Bahir Dar milk shed area, Ethiopia. School of Graduate Studies of Haramaya University.

20. Matthewman RW (1993) Dairying, The tropical agriculturist. CTA publication, Waginingen, the Netherlands, pp. 23-31.

21. Murphy SC, Boor KJ (2000) Trouble-shooting sources and causes of high bacteria counts in raw milk. Dairy, Food and Environmental Sanitation 20: 606-611.

22. Ruegg L (2006) Role of hygienic in efficient milking. WCDS advances in Dairy Technology. Department of Dairy Science, University of Wisconsin 18: 285-293.

23. Gonfa A, Haward AF, Wilhelm HH (2001) Field survey and literature review on traditional fermented. 